\title{
Vaginal Leiomyosarcoma
}

National Cancer Institute

\section{Source}

National Cancer Institute. Vaginal Leiomyosarcoma. NCI Thesaurus. Code C6326.

An aggressive malignant smooth muscle neoplasm, arising from the vagina. It is characterized by a proliferation of neoplastic spindle cells. 